\title{
Correction to: Indoor air fungal pollution of a historical museum, Egypt: a case study
}

\author{
Abdel Hameed A. Awad - Yuosra Saeed - Alia A. Shakour • Nasser M. Abdellatif • \\ Yasser H. Ibrahim • Manal Elghanam • Fatma Elwakeel
}

Published online: 5 February 2020

(C) Springer Nature B.V. 2020

Correction to: Aerobiologia

https://doi.org/10.1007/s10453-019-09623-w

The article "Indoor air fungal pollution of a historical museum, Egypt: a case study", written by "Abdel Hameed A. Awad, Yuosra Saeed, Alia A. Shakour, Nasser M. Abdellatif, Yasser H. Ibrahim, Manal
Elghanam and Fatma Elwakeel" was originally published electronically on the publisher's Internet portal (currently SpringerLink) on 02 January 2020 with open access.

With the author(s)' decision to step back from Open Choice, the copyright of the article changed on 05 February 2020 to (C) Springer Nature B.V. 2020 and the article is forthwith distributed under the terms of copyright.

The original article has been corrected.
The original article can be found online at https:// doi.org/10.1007/s10453-019-09623-w.

A. H. A. Awad ( $₫)$ · Y. Saeed · A. A. Shakour ·

N. M. Abdellatif · Y. H. Ibrahim

Air Pollution Research Department, National Research

Centre, P.O. 12622, Dokki, Giza, Egypt

e-mail: abed196498@yahoo.com

M. Elghanam · F. Elwakeel

Restoration and Conservation Department, National

Museum of Egyptian Civilization, Cairo, Egypt 